УДК 340.15

DOI https://doi.org/10.32844/2618-1258.2019.1-1.11

\title{
ПИРТКО М.С.
}

\section{ПРАВОВІ РЕФОРМИ В АВСТРІЙСЬКІЙ МОНАРХІЇ В ПЕРІОД ПРАВЛІННЯ МАРІЇ ТЕРЕЗІЇ (1740-1780 РР.)}

У статті проаналізовано соціально-політичні передумови та дано теоретичне обгрунтування правових реформ Марії Терезії в Австрійській монархії (17401780 рр.). Значну увагу зосереджено на характеристиці теоретичного обгрунтування реформатської політики епохи освіченого абсолютизму в Австрійській монархії, яка носила еклектичний, компілятивний характер і передбачала основні принципи взаємовідносин влади й суспільства. Обгрунтовуючи способи управління і здійснення завдань держави, правники-теоретики визначали «загальний добробут» у державі як найважливішу мету. Крім цього, мислителі XVIII ст. висунули найважливіший принцип теорії і практики державного управління, за якого головною умовою повноцінного функціонування правової держави став розподіл влади на законодавчу, виконавчу і судову.

У XVIII ст. австрійська влада вдалася до вдосконалення та кодифікації законодавства, ініціювавши роботу над кримінальним та цивільним кодексами. Починаючи 31753 р. розпочалася праця над проектом нового австрійського цивільного кодексу. Компіляційна комісія, яку складали юристи Чехії, Моравії, Австрії і Штиpiï, на чолі з професором Йозефом фон Аццоні (1712-1760 рр.), уніфікувала цивільно-процесуальне законодавство, намагаючись максимально зберегти елементи звичаєвого, римського і природного права. У той час, коли тривала робота над цивільним кодексом, в 1763 р. в Австрії був затверджений кодекс вексельного права. Документ складався усього 353 статті, норми яких регулювали кредитні питання в монархії Габсбургів. А 1766 р. з'явився компілятивний «Терезіанський кодекс» (Codex Theresianus), складений із трьох розділів у восьми томах (усього $8358 \S \S$ ). Канцлер В. Кауніц був певним, що цей кодекс не надається до практичного застосування в юриспруденції. Підписувати його відмовилася і Марія Терезія. Відтак Кауніц запропонував спростити деякі положення і чіткіше класифікувати правові поняття, що, зрештою, успішно зробив Йоганн Бернгард Гортен (1735-1786 pp.).

При цьому внаслідок реформ у дусі освіченого абсолютизму у 1749 р. питання судочинства забрали від Директоріуму і передали у відання новоствореної Верховної палати юстиції.

Ключові слова: правові реформи, освічений абсолютизм, державна влада, правова сфера, Австрійська монархія.

The article analyzes the sociopolitical background and gives theoretical justification of Maria Theresa's legal reforms in the Austrian monarchy (1740-1780's). Considerable attention is paid to the characterization of the theoretical basis of the reform policy of the era of enlightened absolutism in the Austrian monarchy, which was of an eclectic, made-up nature, and envisaged the basic principles of the relationship between power and society. Justifying the ways of managing and fulfilling the tasks of the state, the theoretical lawyers defined the "general welfare" in the state as the most important goal. Also, thinkers of the XVIII century put forward the most important principle of the theory and practice of public administration, in which the main condition for the full functioning of the rule of law was the division of power into legislative, executive and judicial.

In the XVIII century. The Austrian authorities have resorted to improving and codifying legislation by initiating work on criminal and civil codes. Beginning in 1753, work began on the draft of the new Austrian Civil Code. The compilation commission,

(C) ПИРТКО М.С. - аспірант кафедри історії держави, права та політико-правових учень (Львівський національний університет імені Івана Франка) 
composed by lawyers from the Czech Republic, Moravia, Austria and Styria, headed by Professor Josef von Azzoni (1712-1760), unified civil procedural law, trying to maximize the elements of customary, Roman and natural law. At the time when the work on the Civil Code continued, in 1763 in Austria, the bill of exchange law was approved. The document consisted of only 53 articles, which regulated credit issues in the Habsburg monarchy. And in 1766 a compilative "Teresa Codex" (Codex Theresianus) appeared, consisting of three sections in eight volumes (only $8358 \S \S$ ). Chancellor V. Kaunitz was certain that this code is not intended for practical application in jurisprudence. Mary Teresa refused to sign it. Consequently, Kaunitz proposed to simplify some of the provisions and to more clearly classify the legal concepts that Johann Bernhard Horden (1735-1786) made, in the end, successfully.

At the same time, due to reforms in the spirit of enlightened absolutism in 1749, issues of legal proceedings were taken away from the Directorate and transferred to the remit of the newly formed Supreme Chamber of Justice.

Key words: legal reforms, enlightened absolutism, state power, legal sphere, Austrian monarchy.

Вступ. Соціально-політичний і правовий розвиток України на сучасному етапі пов'язаний із здійсненням державно-правових реформ, приведенням чинного законодавства України до європейських та світовий стандартів. У сучасних умовах розвитку Української держави першочерговим завданням $\epsilon$ реформування правової системи, яка $\epsilon$ основою функціонування демократичної держави. Сьогодні правова реформа $\epsilon$ одним із важливих зобов'язань України у рамках Угоди про асоціацію з Європейським Союзом. Реформування правової системи України передбачає вдосконалення правового регулювання суспільних відносин на засадах рівності та справедливості.

Постановка проблеми. Актуальним видається завдання проаналізувати соціально-політичні передумови та теоретичне обгрунтування правових реформ Марії Терезії Австрійській імперії (1740-1780 рр.). Актуалізує дану тему цього дослідження пошук у сучасний період в Україні ефективної моделі формування та функціонування державно-правової системи і створення законодавства, які б відповідали вимогам європейських стандартів. Завдяки історичній ретроспективі можна встановити, що на сучасному етапі розвитку державної політики все більше виокремлюються проблемні питання, пов'язані з ефективним регулюванням суспільних відносин у сучасній Україні. Тому для вдосконалення сучасної правової системи в Україні необхідним $є$ переосмислити, узагальнити як національний, так і міжнародний історичний досвід, вивчити його позитивні і негативні аспекти, а відтак використати все корисне і необхідне для сучасного розвитку України. Крім цього, в сучасній Україні важливо врахувати історичний правовий досвід і використати результати наукових досліджень для вдосконалення чинного законодавства України.

Стан дослідження. В історико-правовій літературі деякі питання визначення соціально-поллітичних передумов та особливостей теоретичного обгрунтування правових реформ Марії Терезії в Австрійській монархії (1740-1780рр.) досліджували такі українські вчені, як: В. Кульчицький, І. Бойко, Б. Тищик, І. Настасяк, М. Никифорак та інші, а також зарубіжні вчені, зокрема: П. Андерсон, О. Бальцер, К. Воцелка, Е. Прістер, Е. Цьольнер та ін.

Постановка завдання. Метою цієї статті є історико-правове з'ясування соціально-політичних передумов та особливостей теоретичного обгрунтування правових реформ Марії Терезії в Австрійській монархії (1740-1780рр.)

Результати дослідження. Для централізованого управління Австрійською державою нагальною стала єдина і цілісна правова система (раціональний чинник), а не надприродне, божественне начало (ірраціональний чинник) [1, s. 294]. Загалом, освічений абсолютизм укріпив ідею правової держави, яка знайшла своє відображення і в політичній думці того часу. Реформи Марії Терезії та її співрегента, а згодом і наступника Йосифа II у сфері юстиції справедливо вважають одними з найбільш успішних в європейській історії нового часу [2, s. 266].

У XVIII ст. австрійська влада вдалася до вдосконалення та кодифікації законодавства, ініціювавши роботу над кримінальним та цивільним кодексами. Починаючи з 1753 р. розпочалася праця над проектом нового австрійського цивільного кодексу [3, с. 345]. Компіляційна комісія, яку складали юристи Чехії, Моравії, Австрії і Штирії, на чолі з професором Йозефом фон Аццоні (1712-1760рр.), уніфікувала цивільно-процесуальне законодавство, намагаючись максимально 
зберегти елементи звичаєвого, римського і природного права. У той час, коли тривала робота над цивільним кодексом, у 1763 р. в Австрії був затверджений кодекс вексельного права. Документ складався усього з 53 статті, норми яких регулювали кредитні питання в монархії Габсбургів [4, с. 58]. A 1766 р. 3'явився компілятивний «Терезіанський кодекс» (Codex Theresianus), складений із трьох розділів у восьми томах (усього $8358 \S \S$ ) [5, s. 22]. Канцлер В. Кауніц був певним, що цей кодекс не надається до практичного застосування в юриспруденції. Підписувати його відмовилася і Марія Терезія. Відтак Кауніц запропонував спростити деякі положення і чіткіше класифікувати правові поняття, що, зрештою, успішно зробив Йоганн Бернгард Гортен (1735-1786 pp.) [6, s. 182].

Порівняно краще юристи справилися зі складанням кримінального кодексу імперії. У 1769 р. кодифіковано кримінальні норми (частина збереглася ще із Середньовіччя), що склали збірник законів «Constitutio criminalis Maria Theresiana» (документ не поширювався на Угорщину). Кодекс складався із двох частин: перша регламентувала процесуальне, а друга - матеріальне право [7, с. 727]. Варто відзначити, що цей збірник не зазнав впливу Просвітництва та природного права і був виконаний у традиційному стилі [8, s. 199]. Терезіана базувалася на інквізиційному процесі, передбачаючи застосування тортур (у виданні кодексу навіть розміщувалися малюнки із зображенням знарядь тортур і поясненнями, як їх застосовувати) [9, с. 58]. Право подавати до суду належало не тільки приватним особам, але й державній владі. Суддя виступав одночасно в ролі обвинувача, захисника, виносив вирок за закритими дверима, дотримуючись формальностей письмового судочинства [10]. Варто відзначити, що Терезіана через свою форму була радше правовим актом для судових органів, а не для підданих [11, s. 100].

Кримінальний кодекс поділяв злочини на публічні - ті, що стосувалися інтересів держави, і на приватні - ті, що стосувалися інтересів приватних осіб. За своїм характером злочини в Терезіані поділялися на дев'ять груп: 1) проти релігії і церкви; 2) проти імператора і держави; 3) проти фінансової системи держави; 4) проти існуючого правопорядку; 5) проти моралі; 6) проти життя і здоров'я; 7) проти майнових прав; 8) проти честі і доброго імені інших осіб; 9) інші злочини. За складністю злочини поділялися на дуже тяжкі (schwere) і легкі (geringere) [9, с. 58].

Відповідно до вчення італійського просвітника і юриста Чезаре Беккаріа (1738-1794рp.) відбулося пом'якшення покарань, а 1776 р. заборонено тортури, покращено умови утримання засуджених у в'язницях. Цьому передувало «вивчення» стану в'язниць. Наприклад, співрегент Йосиф II у 1773 р. відвідав Львів та оглянув місцеві тюрми, якими залишився незадоволеним. Уже у Відні він заборонив надалі використовувати важкі середньовічні колодки, в які замикали в'язнів. Будучи здивованим побаченим, для детального вивчення юридичної системи краю Йосиф II вислав до Львова барона Бургіньйона [13, с. 51]. Подібним чином майбутній імператор відвідував фортецю Шпільберг у Моравії, де вирішив особисто відчути на собі стан людини, закованої в спеціальні кайдани. Після півгодинного випробування Йосиф II дав вказівку скасувати цей вид покарання у Шпільберзі, а згодом у всій Австрії [13, с. 51].

Потребу ліквідації середньовічних покарань обгрунтував Й. Зонненфельс, автор брошури «Ueber Abschaffung der Tortur» (1775 р.), яка справила помітний вплив на Марію Терезію. Зрештою, це цілком відповідало життєвому принципові імператриці, гаслом якої була фраза «Справедливістю і м’якістю» («Justitia et Clementia») [14, c. 177]. Із середини 1770-х років імператриця видала низку розпоряджень й інструкцій стосовно поведінки із засудженими у в'язницях. Смертну кару могли застосовувати тільки зі згоди імператорського двору, до того ж ії застосовували все рідше [15, арк. 1-4]. Починаючи з 1774 р. питання «життя і смерті» перебувало у віданні Вищого суду у Відні і кількість таких звернень зростала: у 1775 р. таких справ в Австрії нараховувалося 545, a 1784 p. - 1153 [16, s. 58]. Щоправда, види смертної кари все ще передбачалися різні: окремі параграфи містили детальні вказівки, як потрібно четвертувати, спалювати живцем, саджати на кіл. Утім, в умовах поширення просвітницьких норм гуманізму до уваги брали обтяжуючі наприклад, злісна умисність) й пом'якшуючі обставини (неповноліття, психічні відхилення тощо) [12, s. 291].

Строгість покарання зіставлялася зі складністю злочину. На першому місці й надалі перебували релігійні мотиви: найтяжче каралися богохульство (заперечення Божого вчення), святотатство, єретизм, чаклунство. 3 богохульством, наприклад, у той час пов'язували появу різних хвороб і стихійних бід. «Кароліна» встановлювала жорстке покарання за чаклунство, особливо коли воно слугувало знаряддям злочину і завдяки йому завдано шкоди людям [17]. Щоправда, у 1770-х роках практично нікого вже не звинувачували у чаклунстві. Наступними за складністю трактувалися злочини проти держави і правителя: образа монарха, державна зрада, підробка грошей і державних паперів. I, нарешті, смертна кара чекала і тих, хто вчинив вбивство [10]. 
Крім «покарання», тогочасне кримінальне законодавство передбачало й заходи, спрямовані на «виправлення і виховання» злочинців. Головним засобом перевиховання вважалася робота, що перетворювало в'язниці імперії в малі мануфактурні підприємства. Наприклад, серед архівних матеріалів знаходимо чимало інформації про виготовлення в'язнями ремісничої продукції, яка успішно конкурувала з речами, виготовленими цеховими майстрами, до того ж за нижчою собівартістю [18, арк. 1].

У період правління Марії Терезії проводилися роботи над стандартизацією німецької мови у сфері права (формулювання і тлумачення законів, подання скарг тощо). Й. Зонненфельсу належать зусилля в напрямку вдосконалення тогочасної юридичної термінології. Розроблені ним принципи ділового стилю під час звернення до суду виглядали таким чином: будь-яке прохання повинно було містити привід звернення, суть прохання і зазначені під порядковими номерами аргументи. Якщо раніше ведення протоколів у місцевих адміністраціях було необов'язковим, то з грудня 1746 р. їх стали вимагати у Верхній Австрії. Запроваджувалися протоколи двох видів: 1) поточні (protocolum exhibitorum); 2) судові (protocolum resolutionum), які включали декрети і резолюції $[19$, s. 8]. У 1752 р. провадження протоколів поширено і на Нижню Австрію, а невдовзі i на інші провінції імперії. Про вагу документообігу засвідчує меморіал канцлера В. Кауніца від 6 вересня 1772 р. й імператорська інструкція від 11 вересня 1772 р., які визначали обов'язковість ретельного документування звернень до адміністрацій [20, арк. 19]. Згідно з декретом Надвірної канцелярії від 22 червня 1772 р. впроваджено предметний, а не хронологічний принцип складання протоколів [19, s. 8-9].

Попри розбудову судової системи в монархії Габсбургів у XVIII ст. реальне відокремлення гілок влади відбулося дещо пізніше. Зокрема, навіть після приєднання Галичини до Австрії функції судових інстанцій здебільшого виконували місцеві адміністрації, наділені відповідними повноваженнями (див. лист канцлеру Кауніцу від 9 липня 1773 р.) [21, арк. 5-8]. Ідейний натхненник реформи правової системи держави, Й. Зонненфельс відкидав ідею розподілу влади, не приділяючи значної уваги і конституційним теоріям. Утім, концепція управління державою, осмислена австрійськими просвітниками, суттєво вплинула на становлення сучасної нормативної теорії правової держави. Саме в період модерної історії усталився принцип «Один закон для всіх» [8, s. 208].

У другій половині XVIII ст. відбулися помітні зміни в судоустрої імперії Габсбургів. Монархи, які втілювали в життя ідеї освіченого абсолютизму, були високої думки про суверенну владу і вважали себе єдиними суддями народного блага. Зокрема, Марія Терезія ініціювала поступове відокремлення адміністрації від судових органів, усунення із законодавства застарілих юридичних норм, уніфікацію розрізнених правових систем. Спочатку при Репрезентаціях, а згодом - при губернаторствах створювалися Сенати юстиції. Держава зосередила у своїх руках усе судочинство, поволі позбавляючи такого права дворянську верству, яка традиційно вершила суд над своїми підданими. У 1768 р. було оголошено, що всі судові органи підвладні монархові, а належну йому судову владу він здійснює через призначуваних судових чиновників. Усі приватні суди, які існували до того, підлягали ліквідації [22, арк. 12-15].

Унаслідок реформ у дусі освіченого абсолютизму в 1749 р. питання судочинства забрали від Директоріуму і передали у відання новоствореної Верховної палати юстиції. Крім того, у Відні було створено Вищий суд (Oberste Justizstelle), який вважався апеляційною інстанцією для всіх спадкових земель і для всіх станів, був відповідальним за весь суддівський персонал. Президент Вищого суду звітував особисто перед імператрицею, що надавало йому особливої ваги. У підпорядкуванні Вищого суду перебували провінційні суди Австрійської імперії [21, арк. 1].

Формування судової системи в регіонах простежимо на прикладі Галичини. Так, згідно з розпорядженням першого генерал-губернатора Королівства Галичини і Володимерії Й. А. Пергена від 20 жовтня 1772 р. було визначено основні принципи судочинства. Зокрема, вироки могли оголошуватися тільки від імені імператора, кожному громадянину гарантувалося право звертатися з апеляцією до губернатора, заборонено звертатися до судів у справах поза їхньою компетенцією [23, с. 154-157].

На початку 1773 р. Марія Терезія своїм декретом передбачила заснування у Львові під керівництвом губернатора апеляційну інстанцію для всіх нижчих судів регіону - Вищий губернаторський суд [24, s. 31-32]. Його радниками виступали урядовці, особисто призначені губернатором Королівства Галичини і Володимерії Й. А. Пергеном. Проте вже 4 липня 1774 р. імператриця видала новий декрет, який стосувався створення нового вищого суду - Королівського трибуналу (tribunale regium), що пізніше отримав назву Імператорсько-королівського трибуналу (tribunale 
caesareo-regium) [25, s. 370]. Першим президентом Королівського трибуналу став таємний радник, наступний губернатор Галичини Генріх фон Ауершперг. 17 вересня 1775 р. до Львова прибув барон Антуан Брунсвік, який обійняв посаду віце-президента Королівського трибуналу. Це означало, що саме він здійснюватиме контроль над судовою системою королівства. Через рік, а саме 8 липня 1775 р. для розгляду апеляцій при Королівському трибуналі створено Апеляційну раду (consilium appellatorium).

15 червня 1774 р. прийнято новий судовий порядок імперії (Gerichts-Ordnung), який визначав процесуальні питання (права й обов'язки сторін, роль свідків, правила судових подань, виконання вироків, подання апеляцій). Загалом, цей документ поділявся на сім розділів, у яких були викладені норми, що стосувалися: 1) прав й обов'язків адвокатів і прокурорів; 2) правил ведення судового процесу і внесення подань; 3) заслуховування свідків (наразі ще не могли виступати за свідків євреї та жінки); 4) побічних суперечок; 5) термінів судового розгляду; 6) відшкодування судових витрат і виконання вироків; 7) перегляду судових рішень й подання апеляцій [26, s. 86]. Чинними залишалися засади писемності, надмірного формалізму і представлення доказів без належної суддівської верифікації. Крім того, було збережено засади диспозиції і вільного заслуховування сторін. Таким чином, встановлювалася змагальна модель цивільного судочинства, що давала можливість сторонам процесу вільно розпоряджатися своїми процесуальними правами. Такий порядок судочинства діяв до 1784 р., поки імператор Йосиф II кардинально не переформатував правову систему імперії [25, s. 373].

Вагоме значення в історії імперії Габсббургів стало створення, починаючи з 1749 р., поліції (з використанням французького досвіду). Й. Зонненфельс трактував «науку про поліцію»,\як вчення про загальну безпеку, а завдання поліції вбачав в «охороні громадського порядку, тиші і спокою» [27, p. 47]. Він допускав право державних органів влади придушувати партикулярні інтереси окремих громадян заради колективних інтересів. Водночас професор Й. Юсті вважається першим систематизатором науки про поліцію або «поліцейського права» (Polizeiwissenschaft). На його думку, поліція повинна відігравати роль посередника між суб'єктами права і державою. Варто відзначити, що цю систематизацію «поліцейського права» Юсті провів як практик, адже у 1755 р. став директором поліції в Геттінгені.

Висновки. Таким чином, діяльність Марії Терезії мала для Австрійської монархії важливе значення. Вона започаткувала й послідовно здійснювала політику переходу від Середньовіччя 3 його дворянсько-кріпосницькими відносинами, всевладдям дворянства та духовенства й безправ'ям широких верств міського і сільського населення до Нового часу. Однією з найважливіших була правова реформи, яка мали на меті оздоровити суспільство, зміцнити та водночас централізувати державу, адаптувати ії до модерних суспільних, економічних і правових умов, нових викликів часу. Вона відображала загальноєвропейські правові тенденції епохи Просвітництва $\mathrm{i}$ належала до найпослідовніших у Свропі. До значних досягнень Марії Терезії можна віднести перші грунтовні кодифікаційні роботи, зокрема, із цивільного права. У 1753 р. створено кілька проектів цивільного кодексу, але жоден не був імператрицею санкціонований. Праця над проектом цивільного кодексу продовжувалась за імператора Йосифа II, який санкціонував цивільний кодекс під назвою «Йозефінський цивільний статут». Він охоплював норми загальної частини цивільного права та норми шлюбно-сімейного права. У 1763 р. Марія-Терезія затвердила Вексельний статут, який стосувався не тільки вексельного, й а торговельного права. Щодо цивільного судочинства, то кодифікаційні роботи у цій галузі права розпочались також при Марії-Терезії. За Марії Терезії у 1752 р. розпочались кодифікаційні роботи в галузі кримінального права і процесу. У 1768 р. опубліковано відповідний кодекс під назвою Constitutio criminalis Theresiana (скорочено - Терезіана). Написаний німецькою мовою з підзаголовками латинською, він грунтувався на Кароліні, попередніх партикулярних збірниках кримінального права, імператорському законодавстві, судовій практиці.

\section{Список використаних джерел:}

1. Krętosz J. Geneza józefińskiej polityki kościelnej cesarza Józefa II w monarchii habsburskiej (1780-1790). Ślaskie Studia Historyczno-Teologiczne. 2001. No 34. S. 292-303.

2. Grodziski S. Porównawcza historia ustrojów państwowych. Kraków : Universitas, 1998. 364 s.

3. Тищик Б., Бойко І. Історія держави і права України: акад. курс : підручник. Київ : Ін Юре, 2015. $808 \mathrm{c}$.

4. Кульчицький В. Державний лад і право в Галичині в другій половині XIX - на початку XX ст. Львів : Машинно-офсетна лабораторія Львівського університету, 1966. 66 с. 
5. Płaza S. Historia prawa w Polsce. Zarys wykładu. Część II. Polska pod zaborami. Kraków : Wydawnictwo «Księgarnia Akademicka», 1993. 208 s.

6. Szabo F. Kaunitz and Enlightened Absolutism 1753-1780. New York : Cambridge University Press, 1994. 380 p.

7. Бойко I. Історія правового регулювання цивільних, кримінальних та процесуальних відносин в Україні (IX-XX ст.) : навч. посіб. для студ. вищ. навч. закладів. Львів : Видавн. Центр ЛНУ імені Івана Франка, 2014. 904 с.

8. Huber A. Österreichische Reichsgeschichte: Geschichte der Staatsbildung und des öffentlichen Rechts. Prag; Wien: F. Tempsky; Leipzig: G. Freytag, 1895. 280 s.

9. Тищик Б. Історія держави і права Австрії та Австро-Угорщини (Х ст.-1918р.): навч. посіб. Львів : Юрид. ф-т Львів. нац. ун-ту імені Івана Франка, 2003. 80 с.

10. Constitutio Criminalis Theresiana. URL : https://archive.org/details/ ConstitutioCriminalisTh eresiana-1768 (дата звернення : 12.02.2018).

11. Moras M. Ordynacja karnoprocesowa Józefa II na tle przemian procesu inkwizycyjnego w monarchii habsburskiej w XVIII wieku. Studia z dziejów panstwa i prawa polskiego. 2011. No 14. S. 97-113.

12. Reicher D. Bureaucracy, «domesticated» elites, and the abolition of capital punishment: processes of stateformation and the number of executions in England and Habsburg Austria between 1700 and 1914. Crime, Law and Social Change. 2010. Vol. 54. No. 3-4. P. 279-297. $230 \mathrm{c}$.

13. Козицький А., Білостоцький С. Кримінальний світ старого Львова. Львів : Афіша, 2001.

14. Ермановская А. Загадки истории Империи Габсбургов. Харьков : Фолио, 2017. 379.

15. Центральний державний історичний архів України у м. Львові (далі - ЦДІА України у м. Львові), ф. 150 (Вищий крайовий суд, м. Львів), оп. 1, спр. 8 (Розпорядження, інструкції і роз'яснення вищих судових органів з питання скасування тортур в тюрмах, 1776-1782 pp.), 12 арк.

16. Wawel-Louis J. Początkowie sądownictwo austriackie w Galici (1772-1784). Lwów : Z drukarni Władysława Łozińskiego, 1897. $416 \mathrm{~s}$.

17. Ströhmer M. Carolina (Constitutio Criminalis Carolina, CCC). Die Peinliche Halsgerichtsordnung Kaiser Karls V. im Kontext der frühneuzeitlichen Hexenprozesse. URL : https://www.historicum.net/themen/hexenforschung/lexikon/sachbegriffe/art/Carolina_Const/html/ artikel/1586/ca/9334b35039/ (дата звернення : 02.11.2017).

18. ЦДІА України у м. Львові, ф. 156, оп. 2, спр. 29 (Справа про розгляд протесту шевців проти пошиття взуття в'язнями львівською тюрми), 49 арк.

19. Górak A., Latawiec K. Kancelaria organów w Galicji. Wybór żródel. Lublin: Wydawn. Uniwersytetu Marii Curie-Skłodowskiej, 2012. 238 s.

20. ЦДІА України у м. Львові, ф. 181, оп. 2, спр. 615 (Циркуляри Марії Терезії у зв’язку з приєднанням до Австрії Галичини й Володимерії), 50 арк.

21. ЦДІА України у м. Львові, ф. 146, оп. 1, спр. 37 (Лист канцлеру Кауніцу про впровадження у Галичині законодавства із судоустрою і судочинства), 19 арк.

22. ЦДІА України у м. Львові ф. 146, оп. 2, спр. 6 (Доповідна записка канцлеру про план адміністративної, державної і суспільно-політичної відбудови Галичини, 1773 р.), 24 арк.

23. Бойко I. Галичина у державно-правовій системі Австрії та Австро-Угорщини (1772$1918)$ : навч. посібник. Львів : ЛНУ імені Івана Франка, 2017. 312 с.

24. Statuitur supremum judicium Gubernatoriale. Edicta et mandata universalia Regnis Galiciae et Lodomeriae. A die 11 Septembr. 1772 initae possessionis promujgata. Leopoli: Typis Viduae Josephae Piller, 1773. S. 31-32.

25. Balzer O. Historia ustroju Austryi w zarysie. Lwów : Jakubowski, 1908. 534 s.

26. Przepisuje porządek sądów tribunalskich, 15 junii 1774. Continuatio edictorum et mandatorum universalium. A die 23 Mensis juni Anno 1773 initae possessionis promulgata. Leopoli : Typis Viduae Josephae Piller, 1774. S. 86.

27. Axtmann R. 'Police' and the Formation of the Modern State. Legal and Ideological Assumptions on State Capacity in the Austrian Lands of the Habsburg Empire, 1500-1800. German History. 1992. Vol. 10. No. 1. P. 39-61. 